\title{
Greenhouse Gas Emissions from Peat Soils Cultivated to Rice Field, Oil Palm and Vegetable
}

\author{
Abdul Hadi ${ }^{1 *}$, Luthfi Fatah ${ }^{1}$, Syaifuddin ${ }^{1}$, Abdullah $^{2}$, Dedi Nursyamsi Affandi ${ }^{3}$, \\ Rosenani Abu Bakar ${ }^{4}$ and Kazuyuki Inubushi ${ }^{5}$ \\ ${ }^{1}$ Faculty of Agriculture; ${ }^{2}$ Faculty of Mathematics and Natural Sciences, Lambung Mangkurat University, \\ South Kalimantan, Indonesia; ${ }^{3}$ Indonesian Agricultural Environment Research Institute, West \\ Java;Indonesia; ${ }^{4}$ Faculty of Agriculture, Universiti Putra Malaysia, Selangor, Malaysia, ${ }^{5}$ Faculty of \\ Horticulture, Chiba University, Chiba, Japan. *: Corresponding Author: Abdul Hadi, Jl. A. Yani KM 37 \\ Banjarbaru, South Kalimantan, Indonesia, e-mail: ahadi@faperta.unlam.ac.id
}

Received 12 December 2011 / accepted 9 April 2012

\begin{abstract}
Presently, about $20 \%$ of oil palm (Elaeis guineensis Jacq) fields in Indonesia are on peat soil, in addition to that other area of peat soil has been conventionally used for rice field and vegetables. To elucidate the global warming potentials of peat soils cultivated to oil palm, vegetable or rice field, field experiment has been carried out in South Kalimantan. Air samples were taken from rice field, oil palm and vegetable fields in weekly basis for six month period and analyzed for concentrations of $\mathrm{N}_{2} \mathrm{O}, \mathrm{CH}_{4}$ and $\mathrm{CO}_{2}$. The global warming potentials (GWP) of the three gases were calculated by multiplying the emission of each gas with their respective mole warming potential. This step was followed by the addition of the three gases' GWP to have the total GWP. The results showed that the emissions of greenhouse gases from peat soils changed seasonally and varied with the crops cultivated. Oil palm has resulted the highest GWP, mostly contributed by $\mathrm{N}_{2} \mathrm{O}$. There was no statistical different in total GWP of paddy and vegetable fields. The annual $\mathrm{N}_{2} \mathrm{O}$ emission from oil palm field was $4,582 \mathrm{~g} \mathrm{~N} \mathrm{ha}^{-1} \mathrm{yr}^{-1}$. Water, nutrients and organic matter managements are among the potential techniques to minimize gas emissions from oil palm field which need field trials.
\end{abstract}

Keywords: Global warming potential, methane, nitrification, nitrous oxide, oil palm (Elaeis guineensis Jacq)

\section{INTRODUCTION}

Peat soil comprises of $6 \%$ of earth surface but retains about $15 \%-30 \%$ of terrestrial carbon and nitrogen (Batjes 1996). This high $\mathrm{C}$ and $\mathrm{N}$ contents have lead peat soil to be thought as a sources of greenhouse gases (GHGs) such as nitrous oxide $\left(\mathrm{N}_{2} \mathrm{O}\right)$, methane $\left(\mathrm{CH}_{4}\right)$ and carbon dioxide $\left(\mathrm{CO}_{2}\right)$ which have global warming potential 1, 23, and 296 in hundred year perspective, respectively (Bouwman 1990).

About 9 million ha of peat soil occurs in the coastal area of Borneo Island (Driesen 1981; Wahyunto et al. 2007) which belongs to three countries (i.e. Indonesia, Malaysia and Brunei). The peat soil in this island is formed from mixture of woody and grassy materials and has long time been used for paddy rice cultivation back to year 1969 (Sabiham 2010). Due to increased demand for biofuel, the peat soil has recently been used for development of oil-producing crops like oil palm

J Trop Soils, Vol. 17, No. 2, 2012: 105-114 ISSN 0852-257X
(Elaeis guineensis Jacq). Presently, about 20\% of oil palm fields in Indonesia and Malaysia are on peat soil (Noor 2010).

It has been estimated that peat and forest degradations contribute to about $45 \%$ of total GHGs emissions from Indonesia (Ridlo 1997). This considerable contribution of peat on total GHG emissions has put peat soil as a target for carbon emission reduction. Peat management is targeted to reduce $9.5-13 \%$ of GHGs emissions from Indonesia by year 2020 (Las and Surmaini 2010). To achieve this target, the government of Indonesia has suspended oil palm development on deep peat and will release a national action plan to minimize GHG emissions from peat (Noor 2010).

Apart from peat burning, about $75 \%$ of $\mathrm{CO}_{2}$, $\mathrm{N}_{2} \mathrm{O}$ and $\mathrm{CH}_{4}$ are believed to be formed by microbial processes in peat soil (Hadi et al. 2001; Murayama and Zahari 1996). Methane is produced by a group of microbes known as methanogens under anaerobic conditions (Cahyani et al. 2004). Meanwhile, $\mathrm{N}_{2} \mathrm{O}$ is produced by nitrifying microorganisms under aerobic conditions and by denitrifying microorganisms under anaerobic conditions (Hadi 
et al. 2012). The different conditions for these gases' formations may resulted a "trade off" effect (i.e. decreasing emission of one gas but at the same time increasing the emissions of other). The objective of present study was to elucidate the global warming potentials of peat soils cultivated to oil palm, vegetable or paddy rice.

\section{MATERIALS AND METHODS}

\section{Site Locations}

The study was carried out in South Kalimantan province (Indonesia), at the border of Hulu Sungai Utara, Hulu Sungai Tengah and Balangan districts covering an area of about 32,370 ha (Figure 1). The area was about $150 \mathrm{~km}$ from the Java ocean and surrounded by Meratus mountains, except for western side which was part of Nagara River basin. The site can be considered as ombrogenic peat where the water are mainly from rain. The peat soil in the area can be classified as a Haplohemist (PT. Saicle Jasa, 2006).

Guided by a land-use map, survey had been carried out to find oil palm, vegetable and paddy rice fields. Considering the easy access for sampling, the sampling points were in radius about 100 meter from collector road. Oil palm was planted in year 2006 (three year old at the time of measurement). Ciherang rice variety was the common rice variety in the area and usually planted in June. Meanwhile, vegetable field was usually

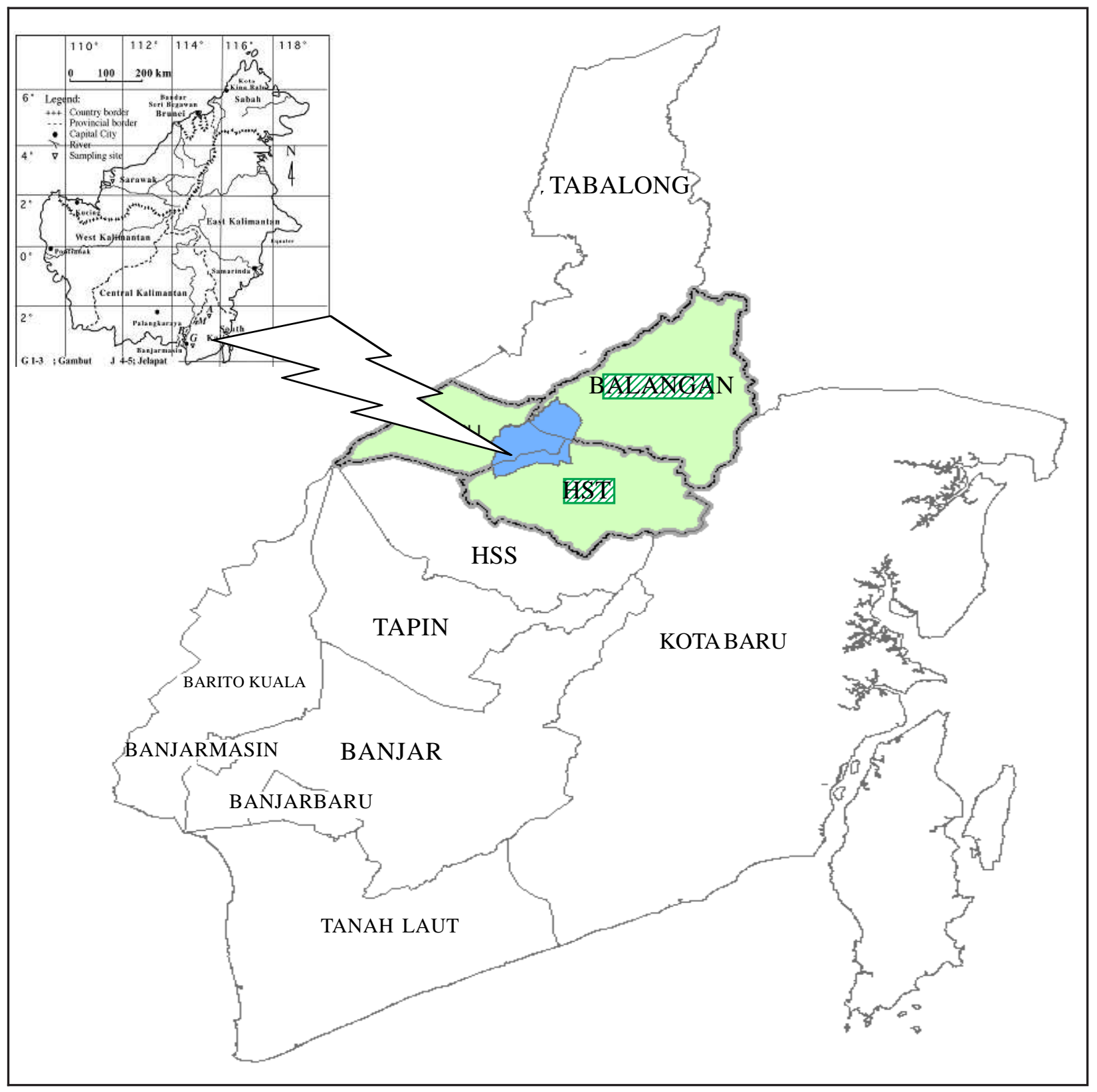

Figure 1. Map of study site. 
cultivated during June to August. No fertilizer has been applied to the fields. The rice field can be considered as rain fed paddy field with zero tillage practice.

\section{Field Settings and Measurements}

Three imaginary plots which about nine meters apart from one to another in oil palm field, vegetable field or paddy field were selected and considered as replications. A piezometer was inserted at each point to reach the ground water table. Redox potential (Eh) electrodes were also inserted to a $10 \mathrm{~cm}$ soil depth at about $30 \mathrm{~cm}$ distanced from the pizometers.

Rectangular (length $50 \mathrm{~cm} \times$ width $50 \mathrm{~cm} \times$ height 50 to $200 \mathrm{~cm}$ ) chambers were used to collect gas samples, depending on height of plants. The chambers had a capillary plastic tube inserted to one site of the chamber through a rubber septum in order to collect air. The chambers were also equipped with fan at the center of the chamber in order to mix the air inside the chamber prior to gas sampling. One oil palm trees (height $150-220 \mathrm{~cm}$ ), four hills of paddy rice (height $45-82 \mathrm{~cm}$ ), and two vegetable plants (tomato and sweet corn; height 0$233 \mathrm{~cm}$ ) were enclosed into the chambers during gas sampling.

Chambers were inserted to beneath about five $\mathrm{cm}$ into the soil. Gas samples were taken by sucking the air inside the chambers through the tube and transferred into a vacuumed bottle (Parkin Elmer, Germany) until the time of analysis. Gas samplings were carried out in weekly basis for six months period (July-November 2009). At the same time, soil $E h$ was measured by an ORP meter (TOA Electronics Ltd, Japan) and the water table was measured manually by inserting a ruler into the pizometer.

Composite soil samples were taken in monthly basis at two soil depths $(0-10 \mathrm{~cm}$ and $10-30 \mathrm{~cm})$ and about $50 \mathrm{~cm}$ from the center of the chambers. The soil samples from all fields (72 samples) were analyzed for soil $\mathrm{pH}$ and soil moisture content. Soils taken in September, October and November (32 samples) were used for determinations of nitrate and water extractable-carbon.

Concentrations of $\mathrm{CH}_{4}$ and $\mathrm{N}_{2} \mathrm{O}$ were quantified by using gas chromatographs. Type, detectors, and working conditions of gas chromatographs were as those given by Hadi et al. (2005). Concentrations of nitrate, and water extractable-C were determined by method described by Hayashi et al. (1997) and Hadi et al. (2000), respectively.

\section{Calculation and Statistical Analysis}

The fluxes (mg C m${ }^{-2} \mathrm{~h}^{-1} \mathrm{CH}_{4}$ or $\mathrm{mg} \mathrm{N} \mathrm{m}^{-2} \mathrm{~h}^{-1}$ for $\mathrm{N}_{2} \mathrm{O}$ ) were calculated according to the following equation (Hadi et al. 2005):

$$
\mathrm{F}=\mathrm{k} \cdot \mathrm{h} \cdot \mathrm{dc} / \mathrm{dt}(273 / \mathrm{T})
$$

where: $k=$ constant for conversion from volume to weigh $\left(\mathrm{N}_{2} \mathrm{O}=1.250 ; \mathrm{CH}_{4}=0.536\right), h=$ height of chamber (meter), $\mathrm{dc} / \mathrm{dt}=$ change in concentration (ppmv) per unit time (hour) and $T=$ air temperature inside the chamber $\left({ }^{\circ} \mathrm{K}\right)$. The annual emissions of greenhouse gases were calculated by multiplying the weighed mean of gas fluxes with time (i.e. one year). Global warming potential of the three gases was calculated by multiplying the annual emissions with the mol warming potential of the gases (i.e. 1, 23 and 296 for $\mathrm{CO}_{2}, \mathrm{CH}_{4}$ and $\mathrm{N}_{2} \mathrm{O}$, respectively) (Bouwman 1990).

The frequency distributions of all gas data were first tested for normality using Lilliefors Test. If normally distributed, differences between treatments were determined by analysis of variance (ANOVA) and least significant differences (LSD) test. All statistical analyses were performed using the "SYSTAT 8.0" statistical package (SPSS, 1996) and were based on $\mathrm{P}<0.05$ significant level.

\section{RESULTS AND DISCUSSION}

\section{Environmental Conditions}

Site descriptions and their soil properties prior to experiment were summarized in Table 1 . The oil palm field was situated at peat dome with elevation $17 \mathrm{~m}$ from mean sea level (MSL), while the vegetable field situated at slop of peat dome with mountain orientation with elevation $15 \mathrm{~m}$ from MSL. The paddy field was at the swamp-orientated slop of the dome with elevation $11 \mathrm{~m}$ from MSL. Peat depths of the three sites ranged from $180 \mathrm{~cm}$ in paddy field to more than $300 \mathrm{~cm}$ in oil palm field. Soil pHs were about five for all sites. Soil C and N ranged from $12-31 \%$ and 0.1 to $1.3 \%$, respectively. Number of bacteria was one or two order of magnitude higher than number of fungi in the three sites.

Ground water tables in the three crop fields varied and changed seasonally. The ground water tables in paddy and vegetable fields fluctuated around $30-77 \mathrm{~cm}$ from ground surface, while the ground water table in oil palm field fluctuated deeper (i.e. $>120 \mathrm{~cm}$ from soil surface). Ditches had been constructed by heavy equipment at oil palm field in order to develop aerobic conditions at root zone of oil palm. Due to high data variability, the $E h$ was 
considered unchanged during the observation period (Figure 2).

\section{Soil Properties}

The $\mathrm{pH}$ in paddy field increased during the first two weeks of the experiment (i.e. 24 July to 9 August) and remained high onward, but the $\mathrm{pH}$ in oil palm field decreased during the first three weeks of experiement and remained low onward (Figure 3). The soil moisture contents did not statistically differ during the observation period, except that was observed in oil palm field taken from $10-30 \mathrm{~cm}$ depth where the soil moisture content decreased and reached minimum on 15 October 2009.

Water extractable-C and $\mathrm{NO}_{3}{ }^{-}$contents varied in the three fields and changed seasonally (Figure 3 ).
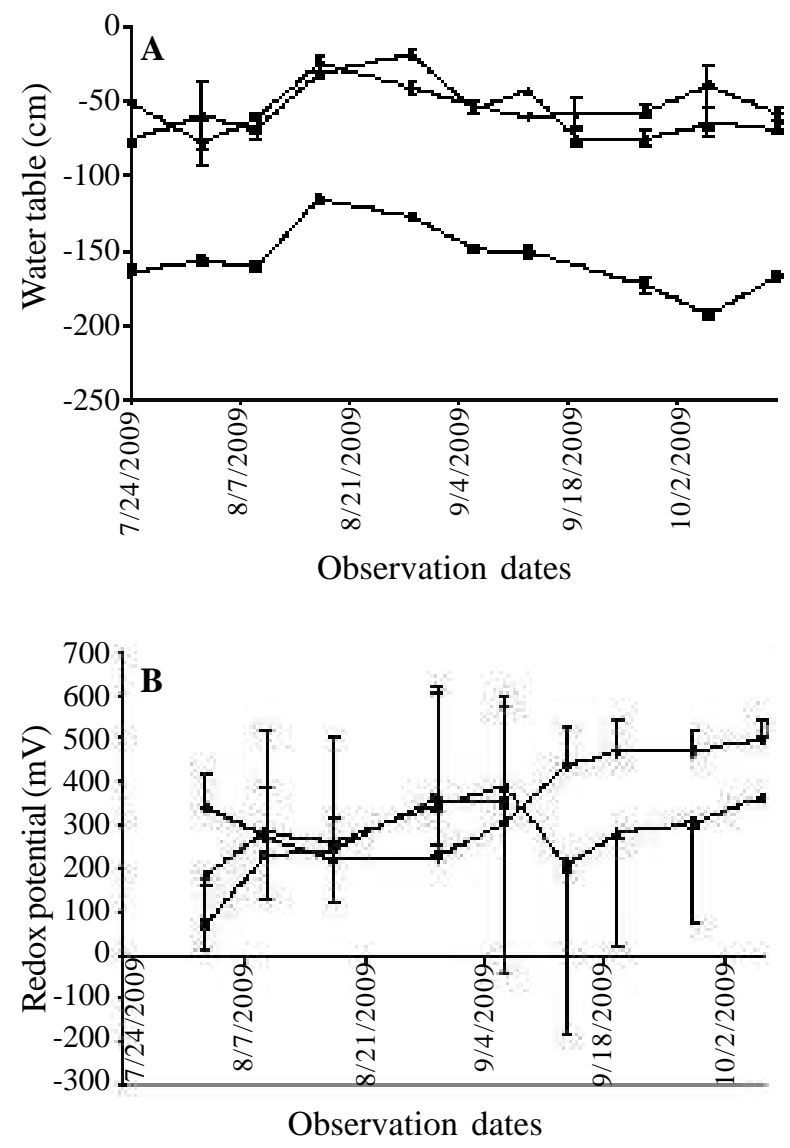

Figure 2. Seasonal changes in water table (A) and redox potential $(E h)(B)$ in the tree crop fields. No $E h$ measurement was carried out in oil palm field on 19 September, 2009 onward. An increase or a decrease bigger than the LSD value of respective crop field was considered as change. In A : $\rightarrow$ paddy (LSD = 25.2), $\rightarrow$ oil palm (LSD $=25.1)$, and $\leftarrow=$ vegetables, in B: $\rightarrow$ paddy $(\mathrm{LSD}=329), \rightarrow$ oil palm $(\mathrm{LSD}=371)$, and $\_=$vegetables (LSD $=455$ ). 

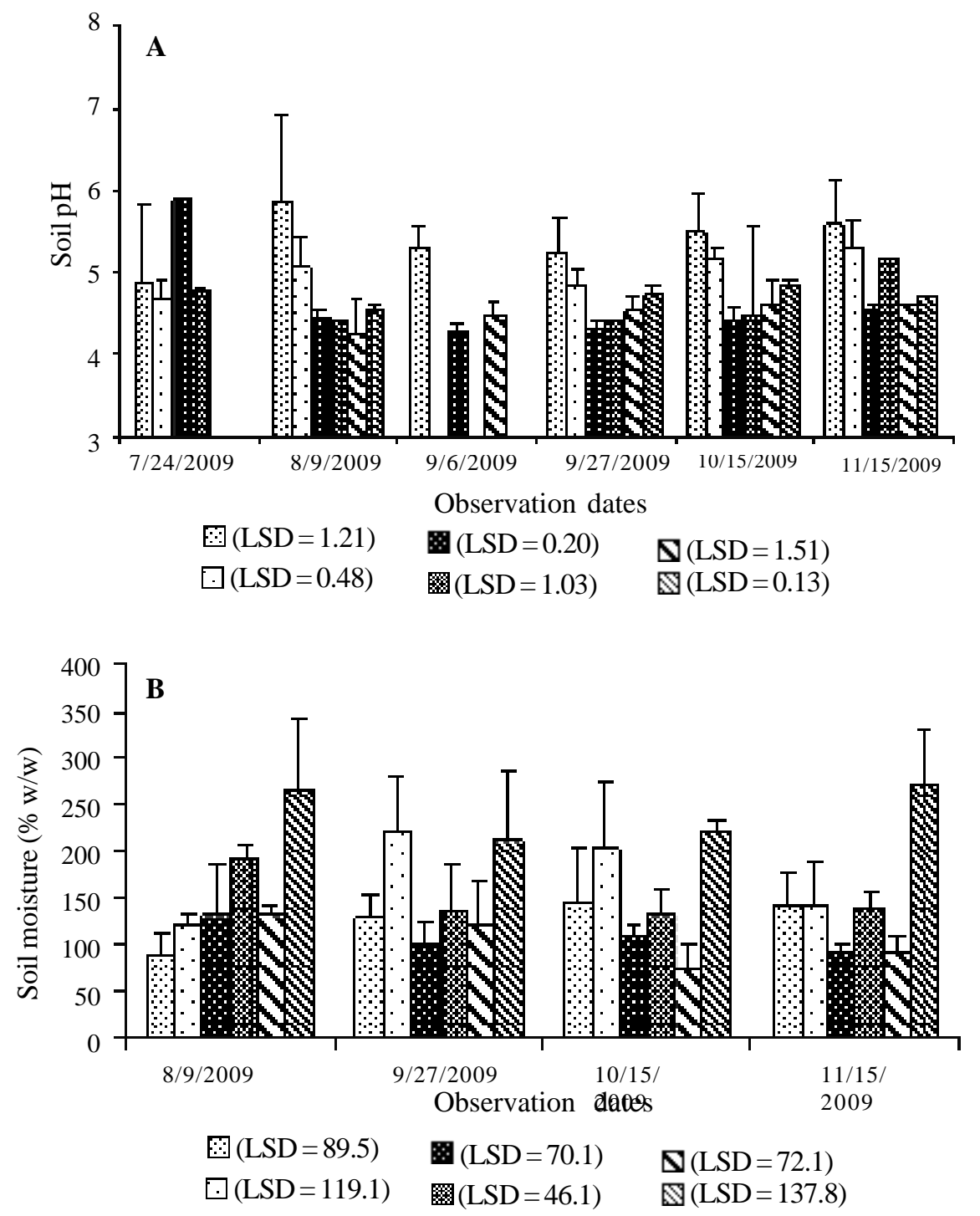
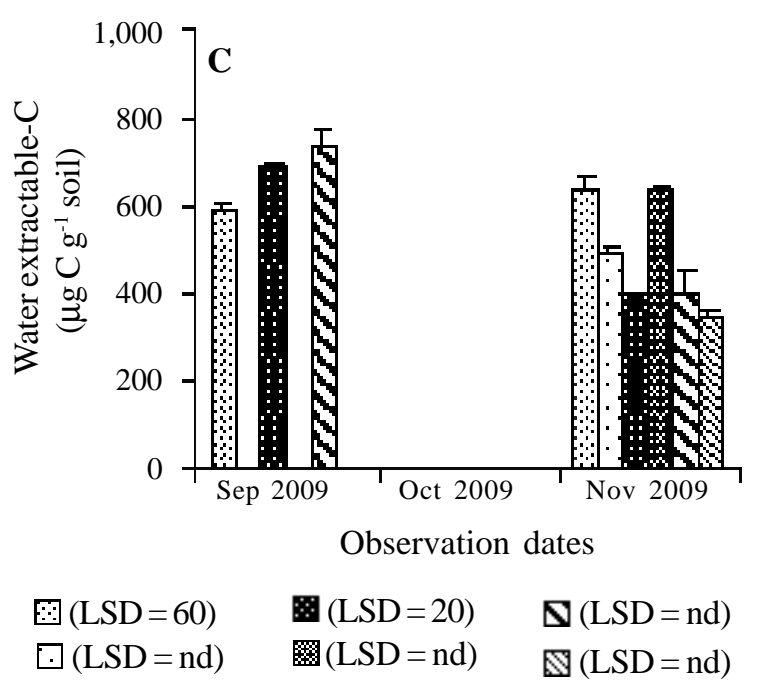

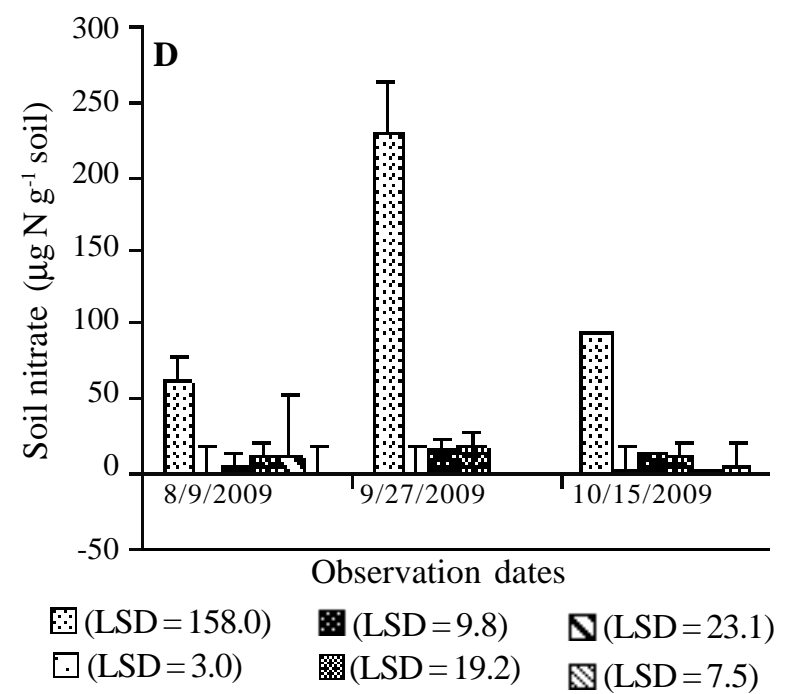

Figure 3. Seasonal changes in soil pH (A), soil moisture (B), and water extractable-C (C) and soil nitrate (D) concentrations taken from $0-10 \mathrm{~cm}$ or $10-30$ soil depths in paddy, oil palm and vegetable fields. An increase or a decrease bigger than the LSD value of respective crop field was considered as change. 웅 = paddy $0-10 \mathrm{~cm}, \square=$ paddy $10-30 \mathrm{~cm}$, 圈= oil palm $0-10 \mathrm{~cm}$, 㘣 = oil palm $10-30 \mathrm{~cm}, \boldsymbol{\nabla}=$ vegetables $0-10 \mathrm{~cm}$, and $\mathbb{N}=$ vegetables $10-30 \mathrm{~cm}$. 
The $\mathrm{NO}_{3}{ }^{-}$concentrations in the three fields generally increased during the half period of the observation and decreased onward. The $\mathrm{NO}_{3}^{-}$concentrations in surface soils of paddy field were higher than the sub-surface soil (10-30 cm soil depth) or the other crop fields.

\section{Greenhouse Gas Emissions}

Seasonal changes in $\mathrm{N}_{2} \mathrm{O}$ and $\mathrm{CH}_{4}$ fluxes are shown in Figure 4. The $\mathrm{N}_{2} \mathrm{O}$ emission from oil palm field had many peaks and reached maximum on 17 August. The $\mathrm{N}_{2} \mathrm{O}$ emission from vegetable field was maximum on 17 August and remained low at the rest of observation period. The $\mathrm{N}_{2} \mathrm{O}$ emission from paddy field were low or even some times negative. Due to high data variability, no statistical different has been identified in $\mathrm{CH}_{4}$ emissions from the three fields. Similarly, no statistical difference has been identified in $\mathrm{CO}_{2}$ emissions from the three fields (data not shown).

The annual $\mathrm{N}_{2} \mathrm{O}$ emission from oil palm field was the highest $\left(4,582 \mathrm{~g} \mathrm{~N} \mathrm{ha}^{-1} \mathrm{yr}^{-1}\right)$ among the three crop fields studied, but no statistical difference was identified in $\mathrm{N}_{2} \mathrm{O}$ emissions from paddy and vegetable fields (Table 2). No statistical difference was identified in $\mathrm{CH}_{4}$ emissions from paddy, oil palm and vegetable fields. Carbon dioxide emissions were the highest in paddy field, but no statistical difference in $\mathrm{CO}_{2}$ emissions from oil palm and vegetable fields has been identified.

Similar patterns of the global warming potential of three gases with that of emissions were observed. In total, the global warming potential was the highest in oil palm field $\left(1.551 \mathrm{~kg} \mathrm{C}-\mathrm{CO}_{2}\right.$ equivalent ha ${ }^{-1}$ $\left.\mathrm{yr}^{-1}\right)$. No statistical different has been identified in global warming potentials in paddy $\left(285.8 \mathrm{~kg} \mathrm{C}-\mathrm{CO}_{2}\right.$ equivalent $\left.\mathrm{ha}^{-1} \mathrm{yr}^{-1}\right)$ and vegetable $\left(401.2 \mathrm{~kg} \mathrm{C}^{-\mathrm{CO}_{2}}\right.$ equivalent $\mathrm{ha}^{-1} \mathrm{yr}^{-1}$ ) fields (Table 2 ).

\section{Discussion}

Peat, organic soil or Histosols are technically all soils which contain appreciable quantities of organic matter $(\mathrm{OM})$ that is considered to dominate the soil properties (Mathur and Farham 1985). Peat soils are formed when the rate of $\mathrm{OM}$ accumulation exceeds the rate of decomposition and can be categorized as deep, medium and shallow peat (Radjagukguk 1990). Peat soil in present study ranged from medium peat in paddy and vegetable fields $(200-300 \mathrm{~cm})$ and deep peat in oil palm field $(>300 \mathrm{~cm})($ Table 1$)$. The $\mathrm{pH}$ and nutrient contents of presented in Table 1 were higher than that average peat (Radjagukguk 1990), probably due to the position of the sites those were far from the ocean hence less influences of pyrite.

Peatlands in South East Asia are naturally submerged and are drained by constructing drainage ditches prior to establishment of crops on them (Sabiham 2010). The depth of drainage ditches depends on the type of crops to be established, which is commonly width and deep for estate crops like oil palm and narrow and shallow for food crops like rice paddy. The differences in dimensions of the ditches result on the variability of ground water table in different crop fields. These practices of crop establishments were also occurred in the study area, where ground water tables in oil palm field were deeper than those in paddy or vegetable fields (Figure 2).

The redox potential reflects the strength of oxidation and reduction reactions in soil (Hesse 1972). Oxygen $\left(\mathrm{O}_{2}\right)$ acts as the electron acceptor in aerobic conditions and will be substituted by oxygenuous compounds like $\mathrm{NO}_{3}^{-}$in anaerobic conditions. Organic matter acts as electron donor at both conditions. The Eh values in present experiment were positive because the Eh electrodes were

Table 2. Emissions of $\mathrm{N}_{2} \mathrm{O}, \mathrm{CH}_{4}$ and $\mathrm{CO}_{2}$ from paddy, oil palm and vegetable fields and their global warming potentials.

\begin{tabular}{|c|c|c|c|c|}
\hline & Parameter & Paddy & Oil Palm & Vegetables \\
\hline \multirow[t]{2}{*}{$\mathrm{N}_{2} \mathrm{O}$} & Emission $\left(\mathrm{g} \mathrm{N} \mathrm{ha}^{-1} \mathrm{yr}^{-1}\right)$ & $-681.6(521.0)$ & $4585.2(1842.4)$ & $927.0(1333.8)$ \\
\hline & GWP $\left(\mathrm{kg} \mathrm{C}-\mathrm{CO}_{2}\right.$ equ ha $\left.{ }^{-1} \mathrm{yr}^{-1}\right)$ & $-201.8(125.9)$ & $1357.2(445.3)$ & $274.4(322.4)$ \\
\hline \multirow[t]{2}{*}{$\mathrm{CH}_{4}$} & Emission $\left(\mathrm{g} \mathrm{C} \mathrm{ha}^{-1} \mathrm{y}^{-1}\right)$ & $16263.4(5916.3)$ & $9841(16510)$ & $1754.1(6286.3)$ \\
\hline & GWP $\left(\mathrm{kg} \mathrm{C}-\mathrm{CO}_{2}\right.$ equ ha $\left.{ }^{-1} \mathrm{yr}^{-1}\right)$ & $374.1(136.1)$ & $226.4(379.7)$ & $40.3(144.6)$ \\
\hline \multirow[t]{2}{*}{$\mathrm{CO}_{2}$} & Emission $\left(\mathrm{g} \mathrm{C} \mathrm{ha}^{-1} \mathrm{yr}^{-1}\right)$ & $113505.1(73695.7)$ & $-33271.6(22995.4)$ & $86446.4(42445.0)$ \\
\hline & GWP $\left(\mathrm{kg} \mathrm{C}^{-\mathrm{CO}_{2}}\right.$ equ ha $\left.{ }^{-1} \mathrm{yr}^{-1}\right)$ & $113.5(60.2)$ & $-33.2(18.8)$ & $86.5(34.7)$ \\
\hline \multicolumn{2}{|c|}{ Total GWP $\left(\mathrm{kg} \mathrm{C}-\mathrm{CO}_{2} \mathrm{equ} \mathrm{ha}^{-1} \mathrm{yr}^{-1}\right)$} & $285.8(356.2)$ & $1550.9(463.3)$ & $401.2(376.0)$ \\
\hline
\end{tabular}

Numbers in parenthesis indicate standard deviations $(n=3)$. Mean followed by the same letters in the same row are not different according to LSD test $(\mathrm{P}<0.05)$. 

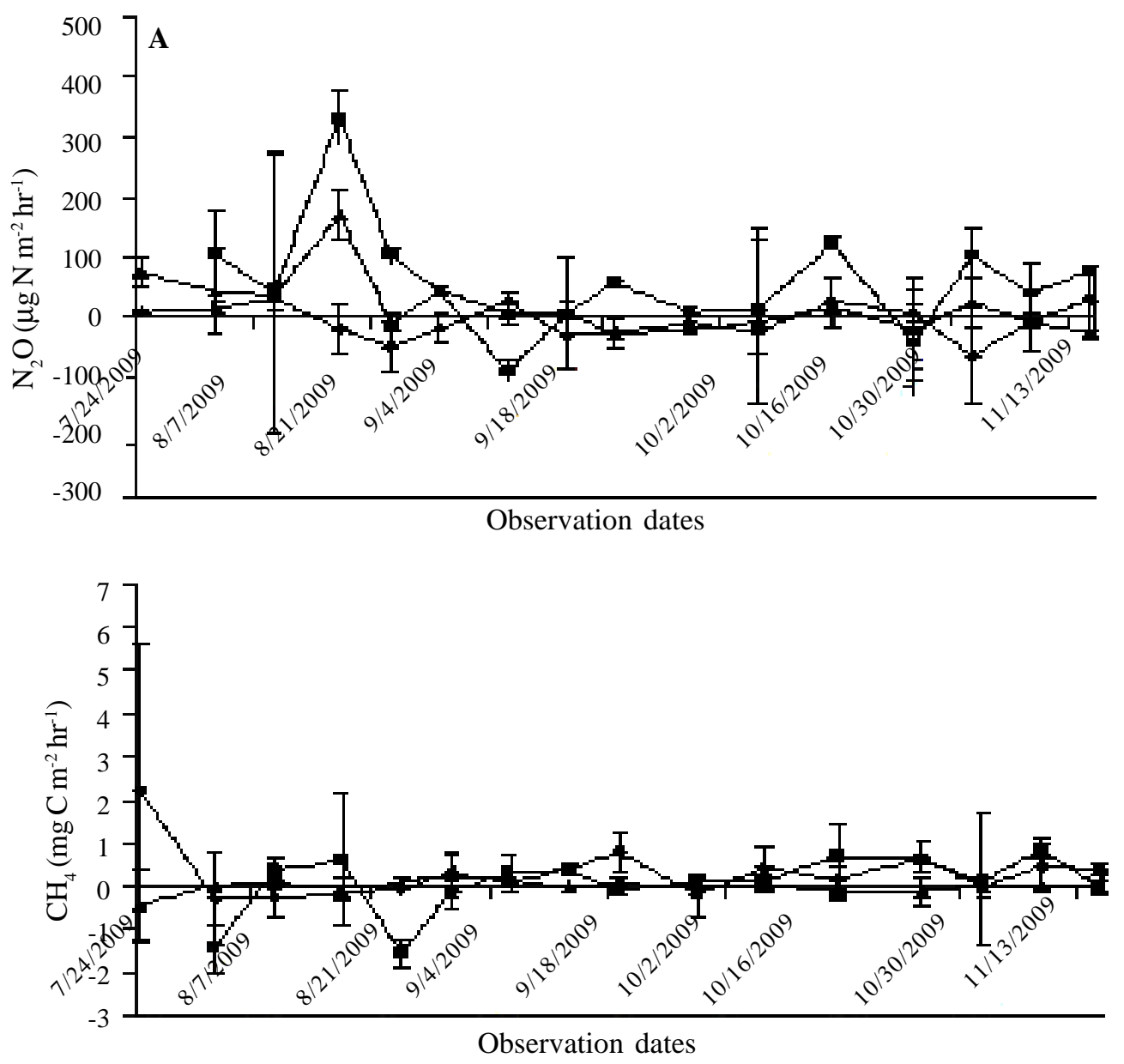

Figure 4. Seasonal changes in $\mathrm{N}_{2} \mathrm{O}(\mathrm{A})$ and $\mathrm{CH}_{4}$ (B) emissions from paddy, oil palm and vegetable fields. An increase or a decrease bigger than the LSD value of respective crop field was considered as change. In A : $\rightarrow$ paddy $(\mathrm{LSD}=61.6), \rightarrow$ oil palm ( $\mathrm{LSD}=137.2)$, and $\leftarrow=$ vegetables $(\mathrm{LSD}=86.3)$, in $\mathrm{B}: \rightarrow$ paddy $(\mathrm{LSD}=1.6)$, $\rightarrow$ oil palm $(\mathrm{LSD}=1.6)$, and $九=$ vegetables $(\mathrm{LSD}=0.5)$.

inserted to the $10 \mathrm{~cm}$ soil depth in the three crop fields those were above ground water table, hence at aerobic conditions. (Figure 2). The Eh values in the three fields tended to be similar due the same reasons as mentioned above (i.e. all were in aerobic conditions).

The patterns of soil $\mathrm{pH}$ in paddy field followed the general trend of wetland soils where the $\mathrm{pH}$ increased in the first two week of submergence of dry soil (Yulius et al. 1985) and were opposite with that occurred in oil palm field (Figure 3). Increase in $\mathrm{pH}$ in paddy field is achieved by the increase of $\mathrm{OH}^{-}$ concentrations during the reduction of $\mathrm{Fe}(\mathrm{OH})_{3}$ to form $\mathrm{Fe}(\mathrm{OH})_{2}, \mathrm{Fe}_{4}(\mathrm{OH})_{8}$ or other ferro hydroxides (Yulius et al. 1985), while the $\mathrm{pH}$ decrease in oil palm field was probably due to the $\mathrm{H}^{+}$formed during the aerobic decomposition of OM. These arguments were also supported by the soil moisture contents in oil palm field where the soil moisture decreased in the early period of observation (Figure 3 ).
The water extractable-C and $\mathrm{NO}_{3}^{-}$in present study were generally higher than those reported by Hadi et al. (2000) in Sarawak, Malaysian side of Borneo island. This indicated the intensive soil OM decomposition in Indonesian side of Borneo (i.e. decomposition level was hemic) as compared to the Malaysian side of Borneo (i.e. decomposition level were generally fibric) where the water table in oil palm fields were shallower $(40-60 \mathrm{~cm})$. This high OM decomposition process may also have contributed to the high release of $\mathrm{N}_{2} \mathrm{O}$ in the oil palm field presently studied (which will be discussed later).

The $\mathrm{N}_{2} \mathrm{O}$ more fluctuated than the other two gases in the three fields (Figure 4), indicating that $\mathrm{N}_{2} \mathrm{O}$ was more responsive to the soil and environmental conditions. Hadi et al. (2000) reported $\mathrm{N}_{2} \mathrm{O}$ response to changes in soil water in which the $\mathrm{N}_{2} \mathrm{O}$ was more from soil with $100 \%$ water holding capacity (WHC) than that from soils with $60 \%$ WHC or submerged conditions. Furukawa et al. (2005) 
also reported a negative correlation between precipitation and $\mathrm{N}_{2} \mathrm{O}$ emission from peat soil in Sumatera island. No differences in $\mathrm{CH}_{4}$ emission from the three fields may indicate that the formations of $\mathrm{CH}_{4}$ were not optimum at aerobic conditions prevailed the three fields. Carbon dioxide was released in paddy and vegetable fields, but was fixed in oil palm field (Table 2).

Emission of $\mathrm{N}_{2} \mathrm{O}$ from oil palm field was high (nearly five $\mathrm{kg} \mathrm{N} \mathrm{ha}^{-1} \mathrm{yr}^{-1}$ ) (Table 2), though no fertilizer had been applied to the fields. This amount was in the same order of magnitude with those reported by Melling et al. (2007) or Takakai et al. (2006) and ought to be increased if $\mathrm{N}$-fertilizer had been applied (Akiyama et al. 2006). This amount of $\mathrm{N}$ is equal to amount that emitted from fertilized mineral soil (Hadi et al. 2008). This big amount of $\mathrm{N}$ loss may contribute to increase in farming cost. Moreover, the $\mathrm{N}_{2} \mathrm{O}$ emission particularly meaningful when we consider its global warming potential which was nearly $1.4 \mathrm{Mg} \mathrm{C}-\mathrm{CO}_{2}$ equivalent ha $^{-1}$ $\mathrm{yr}^{-1}$ in case of oil palm (Table 2).

Our present study considered three greenhouse gases together (i.e. presented as total GWP) (Table 2), which were not realized in previous studies (Hadi et al. 2005; Inubushi et al. 2003; Melling et al. 2007; Takakai et al. 2006). This may easy decision makers or policy makers to asses the benefit of a technology in minimizing greenhouse gas emissions. Difficulties encountered by separate consideration (Tsuruta et al. 1995) could be solved by this notion. By considering total GWP, Hadi et al. (2010) has proved the advantage of intermittent drainage in minimizing GHG emissions from peaty paddy fields in Indonesia and Japan.

In total, oil palm resulted the highest global warming (Table 2), suggesting that innovative technology to minimize $\mathrm{N}_{2} \mathrm{O}$ emission from peat soil cultivated to oil palm should urgently be investigated. Water, nutrients and OM managements are among the potential techniques to minimize gas emissions from oil palm field. Current practice of water management in oil palm is to maintain water table at 50-75 cm (Singh, 2007). In the future, oil palm fields may be kept water-saturated since oil palm can adapt with submerged conditions (Soon 2007). Yanai et al. (2007) has reported the use of charcoal in reducing $\mathrm{N}_{2} \mathrm{O}$ emission through nutrient sorption by the charcoal in a laboratory incubation experiment. Fresh OM incorporation to or dumping on peat soil should be avoided since it will promote GHG emissions (Hadi et al. 2000; Inubushi et al. 2007). Field trials to asses the effect of these mitigation options are needed if the peat soil are continually be used for oil palm cultivation.

\section{CONCLUSIONS}

It could be concluded that the emissions of greenhouse gases from peat soil in Borneo changed seasonally and varied with the type of crops cultivated. Oil palm has resulted the highest global warming potential, mostly contributed by $\mathrm{N}_{2} \mathrm{O}$. There was no statistical different in total global warming potential of paddy and vegetable fields. These findings indicated that innovative technology to minimize $\mathrm{N}_{2} \mathrm{O}$ emission from peat soil cultivated to oil palm should urgently be investigated. Water, nutrients and $\mathrm{OM}$ managements are among the potential techniques to minimize gas emissions from oil palm field which need field trials.

\section{ACKNOWLEDGEMENTS}

We acknowledged the help of Ms. Normahrita and Ms. Dina Berlianti (Faculty of Mathematic and Natural Sciences, Lambung Mangkurat University) for the laboratory measurements. Field work was possible by the help of Mr. Bahtiar Rifai and Mr. Nanang Alfianto (Faculty of Agriculture, Lambung Mangkurat University). The cooperative effort of farmers at study sites were highly appreciated. This work was partly supported by Indonesian Minister of National Education through Grant for Foreign Collaborative Research and International Publication (contract no. 432/SP2H/PP/DP2M/VI/2010).

\section{REFERENCES}

Akiyama H, X Yan and K Yagi. 2006. Estimation of emission factors for fertilizer-induced direct $\mathrm{N}_{2} \mathrm{O}$ emissions from agricultural soil in Japan: Summary of available data. Soil Sci Plant Nutr 52: 774-787.

Batjes NH. 1996. Total carbon and nitrogen in the soil of the world. Eur J Soil Sci 47: 151-163.

Bouwman AF. 1990. Introduction. In: Bourman AF (Ed) Soils and the Greenhouse Effect. John Wiley \& Sons, New York. pp. 25-35.

Driesen PM. 1981. Peat soil. In: IRRI (Ed) Soil and Rice. IRRI, Los Banos, pp. 763-779.

Cahyani VR, K Matsuya, S Asakawa and M Kimura. 2004. Succession and phylogenetic profile of methanogenic archaeal communities during composting processes of rice straw estimated by PCR-DGGE analysis. Soil Sci Plant Nutr 50: 555563. 
Furukawa Y, K Inubushi, M Ali, AM Itang and H Tsuruta. 2005. Effect of changing ground water levels caused by land-use changes on greenhouse gas flux from Tropical peatlands. Nutr Cycl Agroecosyst 71: 8191.

Hadi A, L Fatah, DN Affandi, RA Bakar and K Inubushi. 2012. Population and genetic diversities of nitrous oxide and methane related bacteria in peat soils of South Kalimantan, Indonesia. Malaysian J Soil Sci 16 (accepted).

Hadi A, O Jumadi, K Inubushi, K Yagi. 2008. Mitigation option for $\mathrm{N}_{2} \mathrm{O}$ emissions from corn field in Kalimantan, Indonesia. Soil Sci Plant Nutr 54: 644649.

Hadi A, K Inubushi, E Purnomo, K Yamakawa and $\mathrm{H}$ Tsurata. 2000. Effect of land-use changes on nitrous oxide $\left(\mathrm{N}_{2} \mathrm{O}\right)$ emission from tropical peatlands. Chemos Glob Changes Sci 2: 347-358.

Hadi A, M Haridi, K Inubushi, E Purnomo, F Razie and H Tsuruta. 2001. Effect of land-use change in tropical soil on the microbial properties and emission of greenhouse gases. Microb Environ 16: 79-86.

Hadi A, K Inubushi, Y Furukawa, E Purnomo, M Rasmadi and H Tsurata. 2005. Greenhouse gas emission from tropical peatlands of Kalimantan. Nutr Cycl Agroecosyst 71: 73-80.

Hadi A, K Inubushi and K Yagi. 2010. Effect of water management on greenhouse gas emissions and microbial properties from paddy fields of Indonesia and Japan. Paddy and Water Environment. Paddy Water Environ 8: 319-324.

Hayashi A, K Sakamoto and T Yoshida. 1997. A rapid method for determination of nitrate in soil by hydrazine reduction procedure. Jpn J Soil Sci Plant Nutr 68: 322-326.

Hesse PR. 1972. A Text Book of Soil Chemistry Analysis. William Clower and Sons, Limited, London. pp. 520.

Inubushi K, A Hadi, M Okazaki and K Yonebayashi. 1998. Effect of converting wetland forest to sago palm plantation on methane gas flux and organic carbon dynamics in tropical peat soil. Hydrol Process 12: 2073-2080.

Inubushi K, Y Furukawa, A Hadi, E Purnomo and $\mathrm{H}$ Tsuruta. 2003. Seasonal changes of $\mathrm{CO}_{2}, \mathrm{CH}_{4}$ and $\mathrm{N}_{2} \mathrm{O}$ fluxes in relation to land-use change in tropical peatlands located in coastal area of south Kalimantan. Chemosphere 52: 603-608.

Inubushi K, A Pranoto, M Hashitani and H Kasai. 2007. Effect of empty fruit bunch dumping on greenhouse gas emissions in oil palm plantation. Proceedings of the Soil Science Conference of Malaysia, 17-19 April, 2007 Sarawak, Malaysia, pp. 1-41.

Las I and W Surmaini. 2010. Perlunya Pengembangan Teknologi Pertanian untuk Menekan Pemanasan Global. Paper on One Day Seminar for Alumni Gathering of Agricultural Faculty of Lambung Mangkurat University, Banjarbaru, March 11, 2010 .
Mathur SP and Farham RS. 1985. Geochemistry of humic substances in natural and cultivated peatlands. In: Aiken (ed) Humic Substances in Soil, Sediment, and Water. John Wiley and Sons, Singapore, pp. 53-85.

Melling L, R Hatano and KJ Goh. 2007. Nitrous oxide emissions from three ecosystem in tropical peatlands of Sarawak, Malaysia. Soil Sci Plant Nutr 53: 792-805.

Murayama S and AB Zahari. 1996. Decomposition of Tropical peat soils: 1. Decomposition kinetics of organic matter of peat soils. JARQ 30: 145-151.

Noor M. 2010. Peatland productivity improvement and work opportunity enlargement. Proceeding Seminar Lokakarya Nasional Pemanfaatan Lahan Gambut Berkelanjutan untuk Pengurangan Kemiskinan dan Percepatan Pembangunan Daerah. Bogor, 28 October, 2010, pp. III-1-III-20 (in Indonesian).

PT Saicle Jasa. 2006. Feasibility study for oil palm plantation of swam area in Hulu Sungai Utara, Departement Pekerjaan Umum, Jakarta (in Indonesian)

Radjagukguk B. 1990. Management of peatland productivity for lowland rice. In: Taher (Ed) Pengelolaan Sawah Bukaan Baru Menunjang Swasembada Pangan dan Program Transmigrasi. Faperta Univ. Prasakti/Balittan, Sukarami, pp. 217235 (in Indonesian with English summary).

Ridlo R. 1997. $\mathrm{CO}_{2}$ emissions at peat reclamation for mega rice project in Central Kalimantan. J Alami 2: 57-58 (in Indonesian)

Sabiham S. 2010. Designing peatland management to support agriculture productions, lesson learned from the past three decades. Proceeding Seminar Lokakarya Nasional Pemanfaatan Lahan Gambut Berkelanjutan untuk Pengurangan Kemiskinan dan Percepatan Pembangunan Daerah. Bogor, 28 October, 2010, pp. III-1-III-20 (in Indonesian).

Singh G. 2007. Sustainable development of peatland in United Plantation Berhad for oil palm. Paper presented at Peatland Conference, Kuala Lumpur.

Soon CP. 2007. Soil resources and plantation agriculture in Malaysia. Proceedings of the Soil Science Conference of Malaysia, 17-19 April, 2007 Sarawak, Malaysia, pp. 1-41.

SPSS 1996. SYSTAT 8.0. SPSS Inc., Chicago, Illinois.

Takakai F, T Morishima, Y Hasihidoko, R Hatano, SH Limin, U Darung U and S Dohong. 2006. Effects of agricultural land-use change and forest fire on $\mathrm{N}_{2} \mathrm{O}$ emission from Tropical peatlands, Central Kalimantan, Indonesia. Soil Sci Plant Nutr 52: 662674.

Tsuruta H, K Yagi, K Kanda and K Hirose 1995. Nitrous oxide emission from rice paddy fields. In Program and Abstract of International Symposium on SoilSource and Sink of Greenhouse Gases, Nanjing, China, p. 12. 
Wahyunto, S Ritung, Suparto and H Subagjo. 2005. Sebaran Gambut dan Kandungan Karbon di Sumatera dan Kalimantan. Wetlands InternationalIndonesia Programmed and Wildlife Habitat Canada. Bogor (in Indonesian).
Yanai Y, K Toyota and M Okazaki. 2007. Effect of charcoal addition on $\mathrm{N}_{2} \mathrm{O}$ emissions from rewetting air-dried soils in short-term laboratory experiment. Soil Sci Plant Nutr 53: 181-188.

Yulius AKP, JL Nanere, Arifin, SSR Somosir, R Tangkaisari, JR Lalapua, B Ibrahim, HAsmadi. 1985. Fundamental of Soil Science, BKS Intim (in Indonesian). 